\title{
A Cross-Sectional Epizootiological Study and Risk Assessment of Foot-Related Lesions and Lameness in Intensive Dairy Sheep Farms
}

\author{
Marios Moschovas ${ }^{1}$, Aphrodite I. Kalogianni ${ }^{1}{ }^{\circledR}$, Panagiotis Simitzis ${ }^{2}{ }^{\circledR}$, Georgios Pavlatos ${ }^{1}$, Stavros Petrouleas ${ }^{1}$, \\ Ioannis Bossis ${ }^{3}$ and Athanasios I. Gelasakis ${ }^{1, *(D)}$ \\ 1 Laboratory of Anatomy and Physiology of Farm Animals, Department of Animal Science, \\ School of Animal Biosciences, Agricultural University of Athens (AUA), Iera Odos 75 str., \\ 11855 Athens, Greece; moschovas@aua.gr (M.M.); afrokalo@aua.gr (A.I.K.); pavlatos1996@gmail.com (G.P.); \\ stud214096@aua.gr (S.P.) \\ 2 Laboratory of Animal Breeding and Husbandry, Department of Animal Science, School of Animal Biosciences, \\ Agricultural University of Athens (AUA), Iera Odos 75 str., 11855 Athens, Greece; pansimitzis@aua.gr \\ 3 Laboratory of Animal Husbandry, Department of Agricultural Sciences, School of Agriculture, Forestry and \\ Natural Resources, Aristotle University of Thessaloniki (AUTH), 54124 Thessaloniki, Greece; \\ bossisi@agro.auth.gr \\ * Correspondence: gelasakis@aua.gr
}

check for updates

Citation: Moschovas, M.; Kalogianni, A.I.; Simitzis, P.; Pavlatos, G.; Petrouleas, S.; Bossis, I.; Gelasakis, A.I. A Cross-Sectional Epizootiological Study and Risk Assessment of Foot-Related Lesions and Lameness in Intensive Dairy Sheep Farms. Animals 2021, 11, 1614. https://doi.org/ $10.3390 /$ ani11061614

Academic Editor: Johann Kofler

Received: 29 April 2021

Accepted: 27 May 2021

Published: 29 May 2021

Publisher's Note: MDPI stays neutral with regard to jurisdictional claims in published maps and institutional affiliations.

Copyright: (c) 2021 by the authors. Licensee MDPI, Basel, Switzerland. This article is an open access article distributed under the terms and conditions of the Creative Commons Attribution (CC BY) license (https:/ / creativecommons.org/licenses/by/ $4.0 /)$.
Simple Summary: Foot-related lameness is one of the most significant welfare issues in farm animals. Contrary to dairy cows and meat sheep breeds, epizootiological data on foot-lesions and associated lameness in dairy sheep are scarce. In this study, data were collected from 30 representative intensive dairy sheep farms. Multivariate statistical analysis was used to produce a typology of intensive farming systems which resulted in the assignment of farms in two distinct clusters. Six hundred adult ewes were randomly selected from six flocks (three flocks per cluster) and a cross-sectional study was implemented to investigate the epizootiology and potential risk factors of foot-related lameness, foot-lesions and diseases. Ovine interdigital dermatitis and infectious footrot were the most common infectious foot diseases, while white line disease and hoof wall cracks were the most prevalent non-infectious lesions. Infectious footrot was the main cause of lameness and increased with age, whereas body condition score was associated with increased prevalence of ovine interdigital dermatitis. Comparisons between the clusters regarding foot-related lameness, foot-diseases and lesions at the animal, the limb, and the hoof level are presented, and relevant literature, mechanisms, hypotheses, and challenges of the field are discussed.

Abstract: Foot-related lameness, foot-diseases and lesions are emerging issues in dairy sheep; however, relevant epizootiological studies are scarce, and risk factors have not been elucidated. The objectives of this cross-sectional study were (i) to address this dearth of knowledge by investigating the epizootiology of lameness-related foot-lesions and diseases, and (ii) to assess the impact of potential risk factors on foot health, in intensive dairy sheep farms. Thirty farms were assigned in two representative clusters using a multivariate statistical analysis. Three farms per cluster and 100 multiparous milking ewes per farm (total $n=600$ ) were selected and enrolled in the study. Foot-related lameness, ovine interdigital dermatitis (OID), infectious footrot (IFR), white line disease, hoof wall cracks, as well as health and welfare traits were recorded. Overall prevalence of foot-related lameness was $9.0 \%$ and was primarily associated with IFR; however, additional infectious and noninfectious foot diseases and lesions also contributed. Among infectious foot diseases, OID was the most prevalent $(21.3 \%)$ followed by IFR $(8.0 \%)$; WLD and hoof wall cracks were the most prevalent non-infectious foot-lesions ( $37.7 \%$ and $15.3 \%$, respectively). IFR and OID prevalence increased with age $(p<0.05)$ and BCS $(p<0.01)$, respectively, suggesting that host-related factors and husbandry practices are important determinants of its occurrence. 
Keywords: lameness; dairy sheep; intensive system; infectious footrot; white line disease; ovine interdigital dermatitis; hoof overgrowth; risk factors; sheep welfare

\section{Introduction}

In recent years, the growing demand for sheep milk and products thereof has resulted in a remarkable increase of the global dairy sheep population (ca. $20.0 \%$ ), and total sheep milk production (ca. 28.0\%) [1]. To address this trend, farming systems have been evolving and adapting to more intensive management schemes, exploiting improved genotypes and modern husbandry practices and technologies. This is mainly evident in developed Mediterranean countries with a long-lasting tradition on dairy sheep farming, and a well-organized sheep milk processing industry (e.g., Greece, Spain, France, Italy, etc.).

Intensification of production has reshaped the labor conditions and the socioeconomic status of farmers, converting sheep farming into an attractive career opportunity for young people in rural and peri-urban areas. It has also led to significant benefits for the dairy sheep sector including: (i) increased productivity; (ii) efficient utilization of available resources (such as high-yielding breeding stocks, modernized infrastructures, specialized labor, alternative feedstuff, and optimized land use); (iii) precision farming through adoption of advanced monitoring systems and husbandry practices; and (iv) the establishment of evidence-based biosecurity and hygiene measures for the control of infectious and parasitic diseases [2]. Nevertheless, a growing public skepticism occurs regarding the ethical treatment of animals and their well-being in intensive farming systems [3]. Indeed, several studies have stressed the emergence of health and welfare issues that further influence public perception challenging the sustainability of farms [4-7]. In addition, heterogeneity of intensive farms in terms of their structure, management, and production methods, minimizes the possibility of universally applicable herd health and disease control protocols [8]. Therefore, an updated, objective, and representative typology of these farms based on their characteristics and animals' health and welfare status is useful for the assessment of flock health management status and the proposal of targeted modifications to address critical challenges.

Lameness is a condition with considerable impact on dairy sheep productivity, health, and welfare. It is defined as the deviation from normal gait caused by a wide range of factors, usually followed by signs of pain or discomfort and described as a clinical sign rather than a disease itself. The most common causes of lameness include various foot and hoof infections and lesions affecting foot tissues (including joints and bones) that lead to a condition collectively described as foot-related lameness [9]. The major infectious causes of foot-related lameness are either bacterial, namely, infectious footrot (IFR) (Dichelobacter nodosus and Fusobacterium necrophorum), contagious ovine digital dermatitis (CODD) (Treponema spp.), ovine interdigital dermatitis (OID) (F. necrophorum), and pedal joint abscess (PJA) (F. necrophorum and Actinomyces pyogenes), or viral, namely, orf (Parapoxvirus), foot and mouth disease (Apthovirus), and bluetongue (Orbivirus). Non-infectious causes of lameness include white line disease (WLD), laminitis, and other foot lesions and injuries (e.g., toe granulomas, hoof wall cracks, overgrown hooves, foreign bodies, etc.) [10].

Foot-related lameness ranks highly on the list of the most important health issues with the potential to significantly undermine animals' performance and farms' sustainability. The reduction on milk yield (ca. $20.0 \%$, ref. [11]), body weight (11.6\%, ref. [12]), and wool production $(8.0 \%$, ref. [12]) has been documented in lame sheep, explaining the considerable monetary losses derived from foot-related lameness. For example, the annual economic losses in the UK and New Zealand due to lameness have been estimated to reach GBP 24-80 M and NZD $11 \mathrm{M}$, respectively [13,14].

It is known that both genetic and environmental factors predispose to foot diseases, lesions, and lameness thereof in sheep [9,14-16]. For example, polymorphisms of the DQA-2 loci in the ovine Major Histocompatibility Complex (MHC-ovar) genes have been 
associated with the immune response of sheep to IFR, demonstrating a pivotal role in the susceptibility or resistance against the disease [17]. Additionally, hoof conformation and hoof keratin quality are fundamental to maintain the foot health status [16], however, selective breeding for these traits has not been extensively applied. Environmental factors predisposing to foot-related lameness include animal management, nutritional status, housing conditions (bedding moisture, ventilation, temperature, etc.), season and climate, farmers' knowledge/skills on foot care, and overall hygiene status [18,19]. Other animal factors potentially affecting foot health in sheep are age, productive stage, and milk yield [9]. Nevertheless, little attention has been paid to foot-related lameness in dairy sheep and the available literature is scarce; thereby, much uncertainty still exists regarding the epizootiology and risk factors of lameness-related foot diseases and lesions [9].

A decade ago, in $40 \%$ of the studied intensive and semi-intensive Chios dairy sheep farms in Greece, prevalence of foot-related lameness was greater than 5.0\% [18], with the prevalent diseases being IFR, OID, PJA, and WLD; since then, farming systems have evolved and foot-related lameness epizootiology is likely to have changed. In meat and wool sheep farms, updated information on foot-related lameness etiology and epizootiology is currently available, underpinning its significance. For example, in the UK, prevalence of specific diseases ranged from $<1.0 \%$ to $>25.0 \%$ [20,21], with more than $80.0 \%$ of meat sheep flocks, reporting an increase on the occurrence of foot-related lameness [21]. Similarly, in dairy cows, various studies in the UK and the USA place foot-related lameness among the most significant health and welfare issues, with the prevalence ranging from 21.0 to $35.0 \%$ [15,22-24]. However, extrapolation of epizootiological data from dairy cows or/and meat and wool sheep and applicability of published research in dairy sheep are problematic (for example, in dairy cattle, foot-related lameness is equally caused by infectious and non-infectious lesions unlike dairy sheep where infectious lesions are more frequently observed in lameness cases). This is due to (i) different species and dissimilar productive orientation, husbandry, health management, and breeding practices at the farm level, and (ii) the regional variety of soil-climatic conditions associated with different production methods. Hence, foot-related lameness cannot be evaluated and prioritized on ad hoc basis and subsequently, the suggestion of lameness mitigation strategies is not possible in intensive dairy sheep farms, although an urgent need to cope with the problem is evident.

To address the aforementioned research gap, the objectives of this cross-sectional study were (i) to investigate and describe the epizootiology of lameness-related foot diseases and lesions, and (ii) to assess the impact of potential risk factors on them, in intensive dairy sheep farms in Greece.

\section{Materials and Methods}

\subsection{Area of the Study}

Thirty intensive dairy sheep farms (high-input farms with considerable capital investment on breeding stocks, labor and infrastructures) were initially included in the study ( $n=10,630$ ewes). The farms were distributed in thirteen counties across Greece (Achaea, Aetolia-Acarnania, Attiki, Drama, Karditsa, Kilkis, Korinthos, Kozani, Larissa, Magnisia, Serres, Thessaloniki, Trikala) as presented in Figure 1, and located mainly in plain areas with the topography ranging from coastal areas to inland plateaus and the climate from typical Mediterranean to continental. 


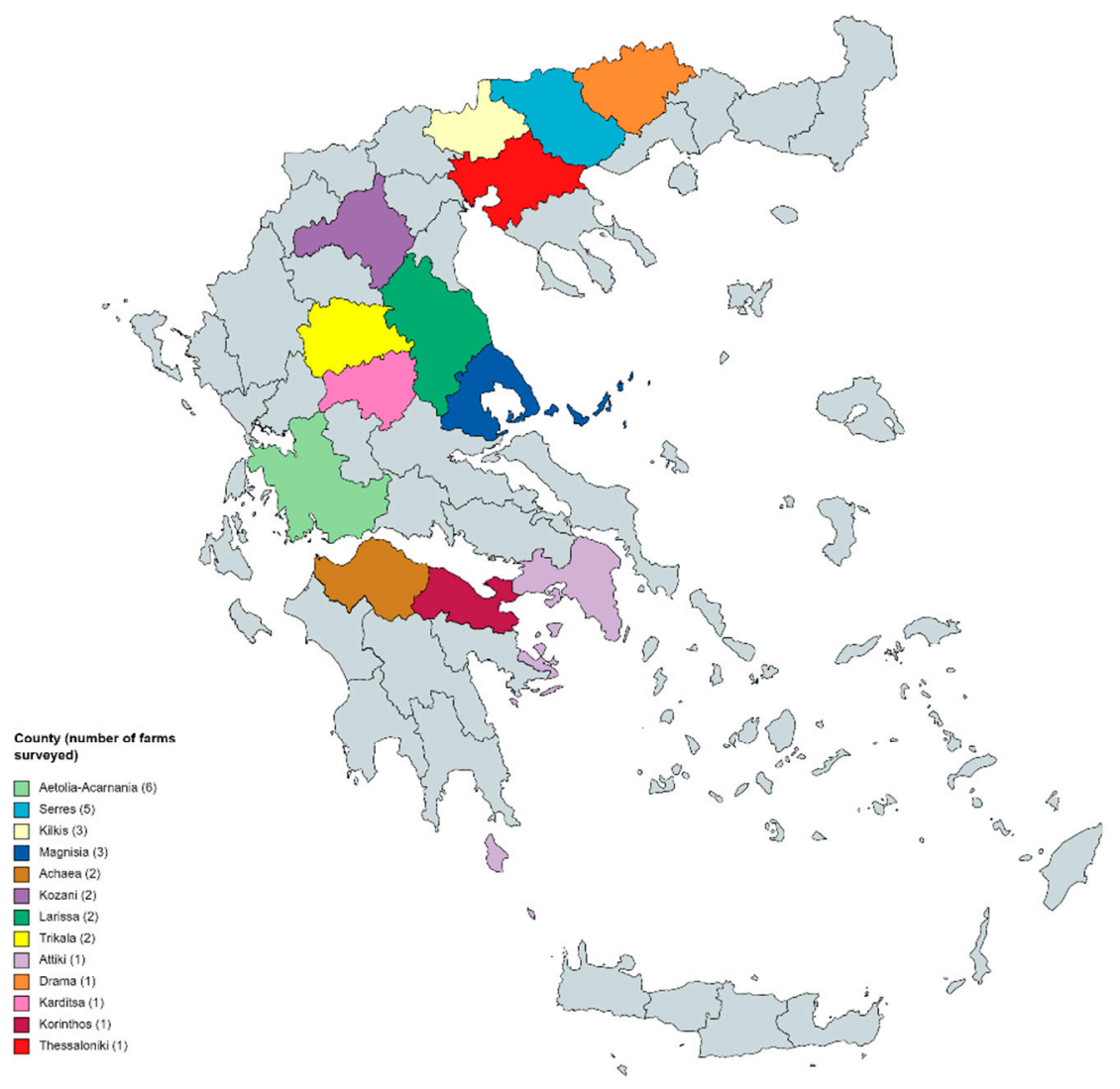

Figure 1. Geographical distribution of the 30 surveyed intensive dairy sheep farms.

Farms were surveyed on-site between May and July 2020, using a structured onpurpose built questionnaire. Data regarding farm structure, flock characteristics and management, labor, infrastructures, feeding and nutrition, reproduction, biosecurity and hygiene measures, disease control protocols, as well as animal overall and foot health status were collected (prevalence, severity, and control measures of lameness-related foot diseases and lesions). A score from 0 to 12 for preventive flock management was calculated assigning one degree for each of the following preventive measures implemented on a regular basis: vaccination against (i) clostridial diseases, (ii) contagious agalactia, (iii) enzootic abortion, (iv) pasteurellosis, (v) gangrenous mastitis, (vi) IFR, (vii) dry-off intramammary antibiotic treatment, (viii) anthelmintic treatment of lambs, (ix) anthelmintic treatment of ewes, (x) vitamin and mineral supplementation, (xi) preventive antibiotic treatment in lambs, and (xii) foot-trimming more than once per year. This score was used as a rough indicator of the preventive veterinary and hygiene status at the flock level.

\subsection{Farm Selection}

A multivariate statistical analysis was used to produce a typology of intensive farming systems by grouping the farms into representative clusters as described in the statistics section below. Based on the results, farms were assigned into two clusters with 22 (Cluster 1) and 8 (Cluster 2) farms, respectively. Three farms per cluster were randomly selected and enrolled in the main study.

\subsection{Animal Selection and Recording}

From each farm, 100 multiparous milking ewes, at the beginning of lactation (20-50 days post-lambing), were randomly selected (total $\mathrm{n}=600$ ewes). The farms were visited during scheduled routine foot-trimming, which was performed by trained personnel under the supervision of two veterinarians. Before and during foot-trimming, one of the veterinarians 
clinically assessed and recorded the hoof wall overgrowth and cracks, as well as the occurrence, topography, and severity of foot diseases and lesions including OID, IFR, and WLD at the hoof level. The other veterinarian performed physical examination of the animals and recorded clinical findings and welfare indicators at the animal level. The recorded traits included (i) body condition score (BCS, 1-5, $1=$ emaciated, $5=$ obese with 0.25 increments) [25], (ii) occurrence of foot-related lameness, arthritis, respiratory disease, ocular and nasal discharge, body abscesses, mastitis, udder lesions and deformities (i.e., skin lesion, abscess, and asymmetry) $(0=$ absence, $1=$ presence), and (iii) wool quality $(0=$ good quality, $1=$ poor quality $)$ and fleece cleanliness $(0=$ clean, $1=$ dirty $)$. Ear tag, breed, and age were also recorded.

\subsection{Statistical Analyses}

SPSS v23 software (IBM Corp., Armonk, NY, USA) was used for the statistical analyses, and statistical significance was set at the 0.05 level. To classify the 30 farms into representative clusters, a two-steps approach was followed. In brief, at the first step, principal component analysis (PCA) was used for data mining purposes, resulting in six principal components (PCs) with eigenvalues greater than 0.8 (Figure 2) to be retained. The six extracted PCs explained about $86.5 \%$ of the total variation described by the nine initially considered variables. However, the Kaiser-Meyer-Olkin measure of sampling adequacy was low (0.338) and Bartlett's test of sphericity was not significant $(p=0.186)$, indicating a poor performance of the PCA; thus, the extracted PCs were not used for the subsequent clustering of the farms. Instead, k-means cluster analysis was used to allocate the farms into two clusters based on factors potentially predisposing to foot-related lameness prevalence (years of farmer's experience, ewes' replacement rate, annual milk yield per ewe, prolificacy, stocking density, and annual incidence of foot-related lameness).

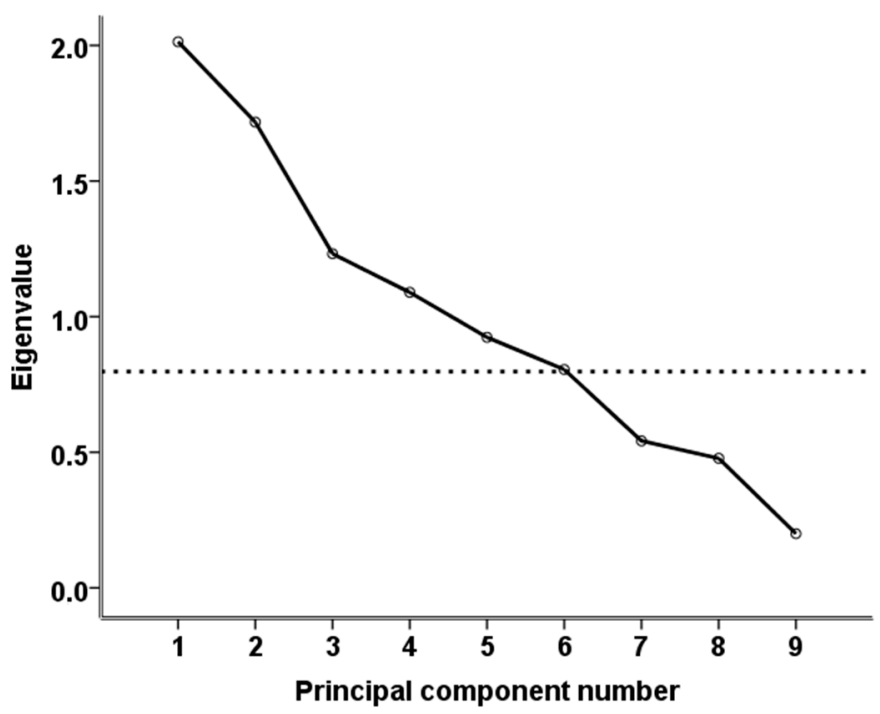

Figure 2. Eigenvalues of the principal components.

Descriptive statistics were estimated (mean \pm standard error), whereas comparisons between the two clusters regarding farm characteristics were performed using analysis of variance (ANOVA). Chi-square test ( $\chi^{2}$ test) was used to compare the prevalence of footrelated lameness and specific non-infectious and infectious foot lesions between (i) the two clusters at the animal-, the limb-, and the hoof level, (ii) front/rear limbs at the limb level, and (iii) front/rear and inner/outer hooves at the hoof level. $\chi^{2}$ test was also used for comparisons between the two clusters considering other recorded health and welfare traits.

For the cross-sectional study, all data were integrated into three databases, corresponding to records at the animal-, the limb-, and the hoof- level (600, 2400, and 4800 records, respectively). Prevalence of (i) lameness, and (ii) lameness-related foot diseases and lesions were estimated. To test the contribution of potential risk factors in predicting the occurrence 
of foot-related lameness, foot diseases and lesions at the animal level, a set of multilevel binary logistic regression models was used, where random effects of farm $j$ and animal $i$ and fixed effects of age, wool quality, and BCS were considered.

$$
\operatorname{Logit}\left[\operatorname{Pr}\left(Y_{i j}=1\right)\right]=\beta_{0 j}+\beta_{1}^{*} A G E_{i j}+\beta_{2}{ }^{*} \mathrm{WOOL}_{i j}+\beta_{3}{ }^{*} \mathrm{BCS}_{i j}+\varepsilon_{i j}
$$

where $\mathrm{Y}_{i j}=$ dependent variable (occurrence of foot-related lameness, OID, IFR, WLD, and hoof wall cracks, on at least one limb), $\beta_{0 j}=$ intercept, $\beta_{1}=$ coefficient of age (AGE) (4 levels), $\beta_{2}=$ coefficient of wool quality (WOOL) (2 levels), $\beta_{3}=$ coefficient of body condition score $(\mathrm{BCS}), \varepsilon_{i j}=$ random residual error.

\section{Results}

\subsection{Descriptives and Comparisons between the Clusters}

Descriptive statistics and comparisons between the two clusters regarding farm and animal characteristics are presented in Table 1. In general, farms in the two clusters had similar structure and characteristics except for (i) milk yield per ewe per lactation which was significantly higher in Cluster 1 (ca. $383 \mathrm{~kg}$ ) compared to Cluster 2 (ca. $257 \mathrm{~kg}$ ) $(p<0.001)$, and (ii) number of empty ewes and abortion rate which were significantly higher ( $p<0.01$ and $p<0.05$, respectively) in Cluster 2 (ca. 10.0\% and $4.0 \%$, respectively) compared to Cluster 1 (ca. $4.0 \%$ and $1.0 \%$, respectively) (Table 1 ).

Table 1. Descriptive statistics (mean \pm standard error) and comparisons between the two clusters regarding farm and animal characteristics.

\begin{tabular}{|c|c|c|c|}
\hline & Cluster $1(n=22)$ & Cluster $2(n=8)$ & $p$-Value \\
\hline Farmers' experience (years) & $10.0 \pm 1.36$ & $8.5 \pm 1.98$ & 0.561 \\
\hline Animals per employee (n) & $159.2 \pm 11.21$ & $128.1 \pm 17.00$ & 0.155 \\
\hline Total animal number $(\mathrm{n})$ & $518.6 \pm 98.00$ & $376.8 \pm 84.47$ & 0.415 \\
\hline Early lambing ewes (n) & $208.6 \pm 42.60$ & $137.4 \pm 28.87$ & 0.339 \\
\hline Late lambing ewes (n) & $167.5 \pm 43.86$ & $104.5 \pm 35.89$ & 0.417 \\
\hline Rams (n) & $15.9 \pm 2.04$ & $13.3 \pm 3.37$ & 0.506 \\
\hline Ewes to ram ratio & $27.6 \pm 3.80$ & $23.4 \pm 2.96$ & 0.524 \\
\hline Rams' replacement (years) & $3.0 \pm 0.27$ & $3.6 \pm 0.46$ & 0.247 \\
\hline Replacement rate $(\%)$ & $24.6 \pm 2.35$ & $23.1 \pm 4.11$ & 0.746 \\
\hline Milk yield/ewe/lactation (kg) & $383.4 \pm 8.76$ & $256.9 \pm 16.88$ & 0.000 \\
\hline Prolificacy (lambs/ewe) & $1.6 \pm 0.10$ & $1.5 \pm 0.11$ & 0.360 \\
\hline Weaning age (days) & $38.6 \pm 1.84$ & $40.0 \pm 3.13$ & 0.698 \\
\hline Lamb carcass weight at weaning $(\mathrm{kg})$ & $10.1 \pm 0.48$ & $10.1 \pm 0.55$ & 0.939 \\
\hline Ewes per ram at mating & $12.6 \pm 2.24$ & $15.6 \pm 2.95$ & 0.469 \\
\hline Empty ewes $(\%)$ & $3.9 \pm 0.81$ & $10.4 \pm 2.67$ & 0.004 \\
\hline Abortion rate (\%) & $1.2 \pm 0.28$ & $2.9 \pm 0.88$ & 0.021 \\
\hline Diarrhea rate in lambs (\%) & $32.6 \pm 8.15$ & $43.3 \pm 11.31$ & 0.487 \\
\hline Mastitis rate $(\%)$ & $4.0 \pm 1.15$ & $4.1 \pm 1.11$ & 0.951 \\
\hline Foot-related lameness rate $(\%)$ & $2.4 \pm 0.50$ & $5.3 \pm 2.31$ & 0.085 \\
\hline Stocking density $\left(\mathrm{m}^{2} /\right.$ ewe $)$ & $2.1 \pm 0.13$ & $1.7 \pm 0.11$ & 0.083 \\
\hline Preventive flock management score (0-12) & $6.1 \pm 1.82$ & $5.6 \pm 1.77$ & 0.538 \\
\hline
\end{tabular}

\subsection{Prevalence of Foot-Related Lameness, Foot Diseases and Lesions at the Animal Level}

A total of 210,98, 230, and 62 ewes of two, three, four, and >four years old, respectively were used for the study. Average BCS of the studied ewes was $2.8 \pm 0.01$. The overall prevalence of foot-related lameness was $9.0 \%(54 / 600)$, and was significantly higher in Cluster $1(11.3 \%, 34 / 300)$ compared to Cluster $2(6.7 \%, 20 / 300)\left[\chi^{2}(1, \mathrm{n}=600)=3.99\right.$, $p<0.05$, Table 2]. The major cause of lameness was IFR $(5.5 \%, 33 / 600)$ and its combination with (i) OID (1.2\%, 7/600), (ii) WLD (1.0\%, 6/600), and (iii) OID and WLD $(0.2 \%, 1 / 600)$; other causes of lameness were WLD $(0.8 \%, 5 / 600)$ and excessive hoof wall overgrowth $(0.3 \%, 2 / 600)$. 
Table 2. Prevalence of foot lesions (OID: Ovine interdigital dermatitis, IFR: Infectious footrot, WLD: White line disease) and other health and welfare traits recorded during clinical examination at the animal level in the two clusters, and comparisons between them.

\begin{tabular}{cccc}
\hline & Prevalence, $\%$ (n) & Prevalence, $\%$ (n) & $p$-Value \\
\hline Cluster 1 (n = 300 ewes) & Cluster 2 (n = 300 ewes) & \\
Lameness & $11.3 \%(34)$ & $6.7 \%(20)$ & 0.046 \\
OID & $16.7 \%(50)$ & $26.0 \%(78)$ & 0.005 \\
IFR & $10.0 \%(30)$ & $6.0 \%(18)$ & 0.071 \\
WLD & $35.0 \%(105)$ & $40.3(121)$ & 0.178 \\
Hoof overgrowth & $99.7 \%(299)$ & $99.0 \%(297)$ & 0.316 \\
Hoof wall cracks & $8.0 \%(48)$ & $7.3 \%(44)$ & 0.650 \\
Arthritis & $3.3 \%(10)$ & $5.7 \%(17)$ & 0.168 \\
Poor wool quality & $11.7 \%(35)$ & $6.0 \%(18)$ & 0.014 \\
Dirty fleece & $58.0 \%(174)$ & $67.0 \%(201)$ & 0.023 \\
Respiratory sound & $1.3 \%(4)$ & $2.7 \%(8)$ & 0.243 \\
Ocular/nasal discharge & $0.3 \%(1)$ & $2.7 \%(8)$ & 0.019 \\
Clinical mastitis & $0.3 \%(1)$ & $3.0 \%(9)$ & 0.011 \\
Udder abscess & $13.7 \%(41)$ & $17.3 \%(52)$ & 0.215 \\
Udder skin lesions & $1.0 \%(3)$ & $14.7 \%(44)$ & 0.000 \\
Udder asymmetry & $31.7 \%(95)$ & $25.0 \%(75)$ & 0.070 \\
Body abscess & $15.3 \%(46)$ & $19.0 \%(57)$ & 0.234 \\
\hline
\end{tabular}

In the case of infectious foot diseases, OID was the most prevalent $(21.3 \%, 128 / 600)$ followed by IFR $(8.0 \%, 48 / 600)$. Regarding non-infectious foot lesions, almost all the studied animals had at least one overgrown hoof $(99.3 \%, 596 / 600)$, whereas the prevalence of WLD and hoof wall cracks were $37.7 \%(226 / 600)$ and $15.3 \%(92 / 600)$, respectively. Prevalence of foot diseases and lesions per age group are presented in Figure 3. All foot lesions were observed in each of the studied farms, with OID, IFR, WLD, and hoof wall cracks prevalence ranging from 7.0 to $48.0 \%, 2.0$ to $14.0 \%, 30.0$ to $51.0 \%$, and $13.0 \%$ to $18.0 \%$, respectively.

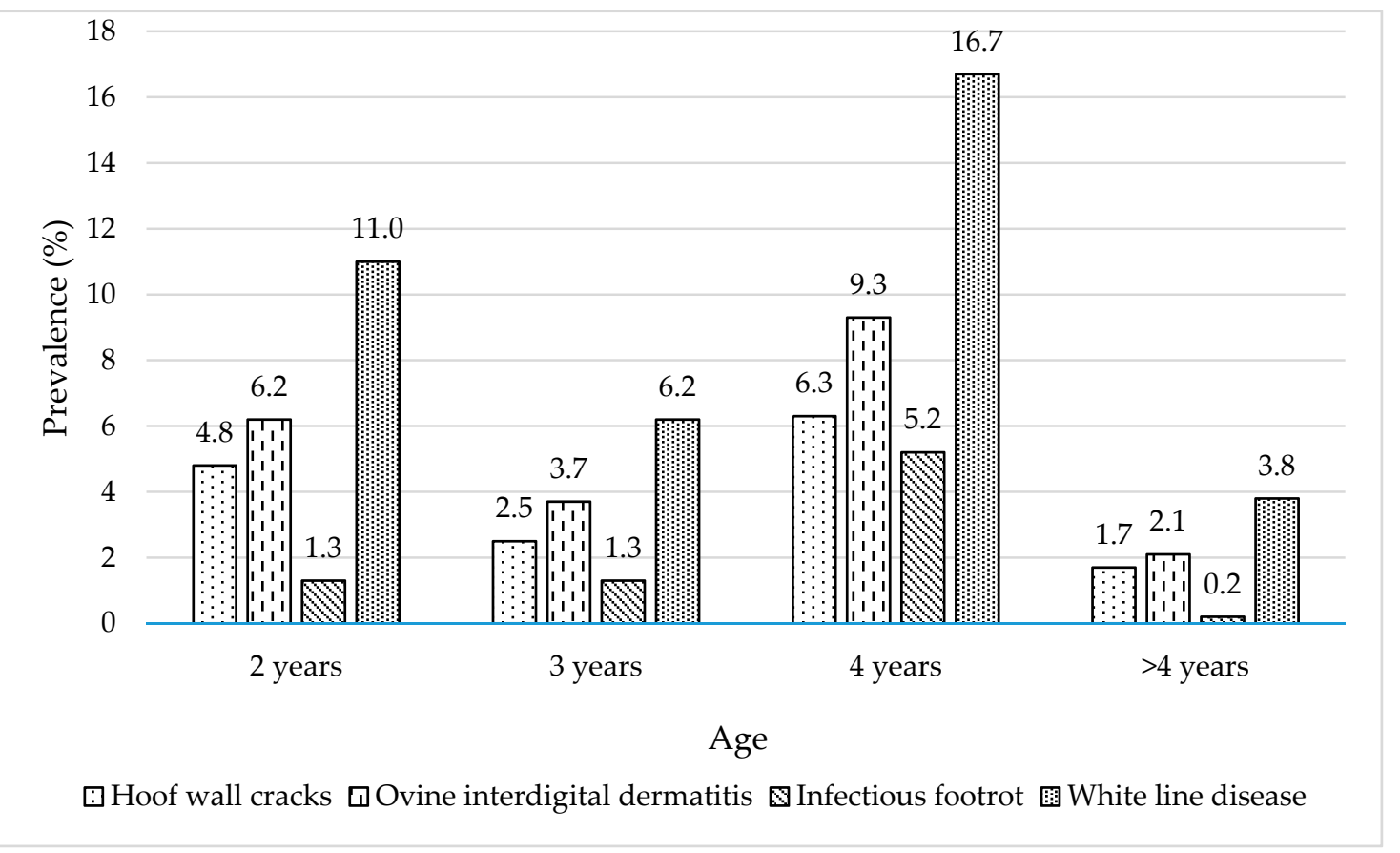

Figure 3. Prevalence of foot diseases and lesions per age group. 
Prevalence of foot lesions, and other health and welfare traits recorded at the animal level, in the two clusters, and comparisons between them are summarized in Table 2; OID prevalence was significantly higher in Cluster $2(p<0.01)$; on the contrary, IFR prevalence tended to be higher in Cluster $1(p=0.071)$.

\subsection{Prevalence of Foot Diseases and Lesions at the Limb Level}

Prevalence of foot diseases and lesions at the limb level and comparisons between (i) the two clusters, and (ii) front/rear limbs in the studied sheep population, are presented in Table 3. IFR prevalence was significantly higher in Cluster 1 compared to Cluster 2 $(p=0.05)$. Additionally, both OID and IFR prevalence were significantly higher in rear compared to front limbs ( $p<0.001$ and $p<0.01$, respectively).

Table 3. Prevalence of foot lesions (OID: Ovine interdigital dermatitis IFR: Infectious footrot WLD: White line disease) at the limb level ( $n=2400$ limbs) and comparisons between (i) the two clusters, and (ii) front/rear limbs in the studied sheep population.

\begin{tabular}{|c|c|c|c|c|}
\hline & & Prevalence, \% (n) & Prevalence, \% (n) & $p$-Value \\
\hline \multirow{6}{*}{ 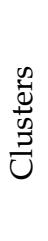 } & & Cluster $1(n=1200)$ & Cluster $2(n=1200)$ & \\
\hline & OID & $8.6 \%(103)$ & $7.7 \%(92)$ & 0.411 \\
\hline & IFR & $2.8 \%(33)$ & $1.6 \%(19)$ & 0.050 \\
\hline & WLD & $12.5 \%(150)$ & $14.7 \%(176)$ & 0.121 \\
\hline & Hoof overgrowth & $98.8 \%(1185)$ & $96.3 \%(1155)$ & 0.000 \\
\hline & Hoof wall cracks & $4.4 \%(53)$ & $4.3 \%(51)$ & 0.841 \\
\hline \multirow{6}{*}{ 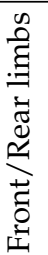 } & & Front limbs $(n=1200)$ & Rear limbs $(n=1200)$ & \\
\hline & OID & $4.2 \%(50)$ & $12.1 \%(145)$ & 0.000 \\
\hline & IFR & $1.3 \%(16)$ & $3.0 \%(36)$ & 0.005 \\
\hline & WLD & $13.4 \%(161)$ & $13.8 \%(165)$ & 0.812 \\
\hline & Hoof overgrowth & $96.9 \%(1163)$ & $98.1 \%(1177)$ & 0.067 \\
\hline & Hoof wall cracks & $4.3 \%(52)$ & $4.3 \%(52)$ & 1.000 \\
\hline
\end{tabular}

Prevalence of foot diseases and hoof lesions according to the number of the affected (i) limbs (OID), and (ii) hooves (IFR, WLD, and hoof wall cracks) are presented in Figure 4.

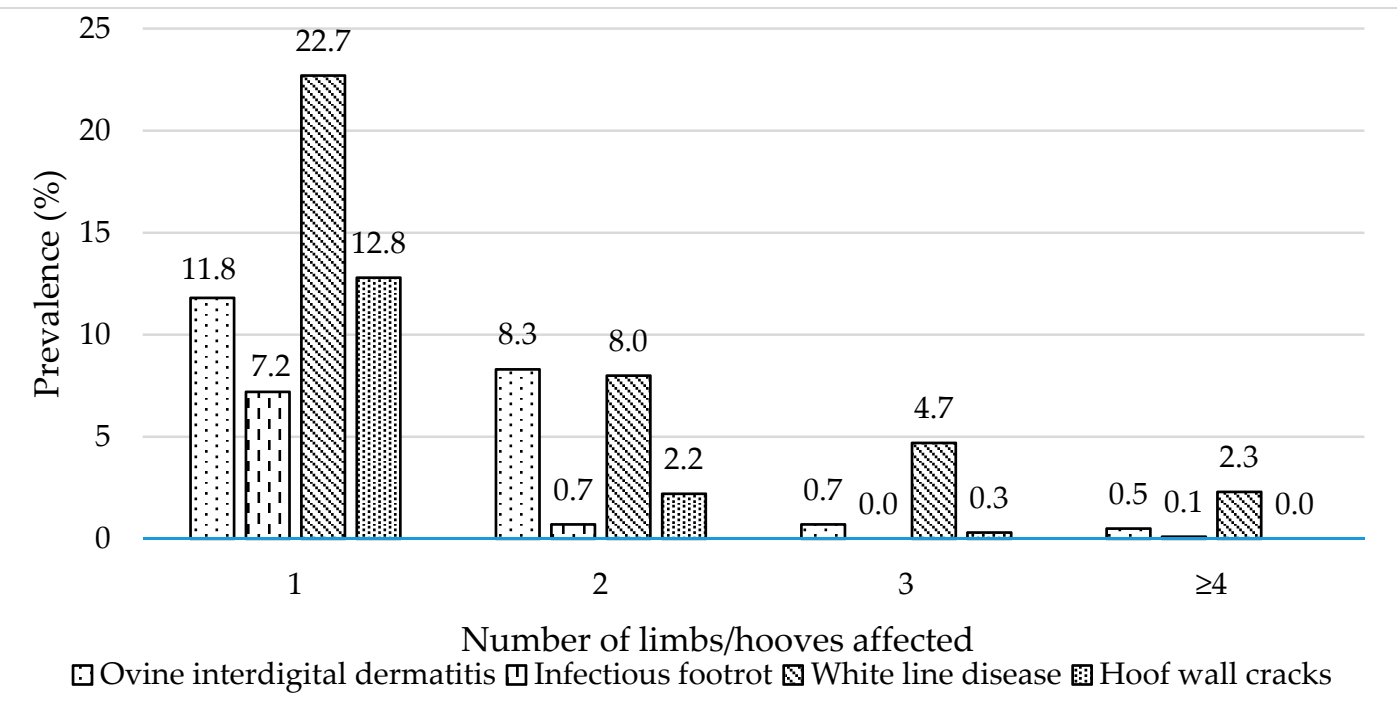

Figure 4. Prevalence of foot diseases and hoof lesions according to the number of the affected (i) limbs (1 to 4 ) (ovine interdigital dermatitis), and (ii) hooves 1 to $\geq 4$ (infectious footrot, white line disease, hoof wall cracks). 


\subsection{Prevalence of Foot Diseases and Lesions at the Hoof Level}

Prevalence of IFR, WLD, hoof wall overgrowth, and hoof wall cracks at the hoof level and comparisons between (i) the two clusters, (ii) front/rear hooves, and (iii) inner/outer hooves are presented in Table 4. IFR prevalence at the hoof level was significantly higher in Cluster 1 compared to Cluster 2 farms $(p<0.05)$, and in rear compared to front hooves $(p<0.01)$.

Table 4. Prevalence of foot lesions (IFR: Infectious footrot, WLD: White line disease) at the hoof level ( $\mathrm{n}=4800$ hooves) and comparisons between (i) the two clusters, (ii) front/rear hooves, and (iii) inner/outer hooves in the studied sheep population.

\begin{tabular}{|c|c|c|c|c|}
\hline & & Prevalence, \% (n) & Prevalence, \% (n) & $p$-Value \\
\hline \multirow{5}{*}{$\begin{array}{l}\frac{\infty}{0} \\
\frac{\vec{d}}{0} \\
\vec{U}\end{array}$} & & Cluster $1(n=2400)$ & Cluster $2(n=2400)$ & \\
\hline & IFR & $1.5 \%(36)$ & $0.8 \%(20)$ & 0.032 \\
\hline & WLD & $7.1 \%(171)$ & $8.6 \%(206)$ & 0.060 \\
\hline & Hoof overgrowth & $96.2 \%(2308)$ & $93.6 \%(2247)$ & 0.000 \\
\hline & Hoof wall cracks & $2.3 \%(55)$ & $2.3 \%(54)$ & 0.923 \\
\hline \multirow{5}{*}{ 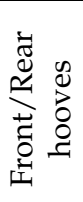 } & & Front hooves $(n=2400)$ & Rear hooves $(n=2400)$ & \\
\hline & IFR & $0.7 \%(17)$ & $1.6 \%(39)$ & 0.003 \\
\hline & WLD & $7.7 \%(185)$ & $8.0 \%(192)$ & 0.707 \\
\hline & Hoof overgrowth & $93.4 \%(2242)$ & $96.4 \%(2313)$ & 0.000 \\
\hline & Hoof wall cracks & $2.3 \%(54)$ & $2.3 \%(55)$ & 0.923 \\
\hline \multirow{5}{*}{ 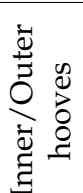 } & & Inner hooves $(n=2400)$ & Outer hooves $(n=2400)$ & \\
\hline & IFR & $1.3 \%(32)$ & $1.0 \%(24)$ & 0.282 \\
\hline & WLD & $7.7 \%(184)$ & $8.0 \%(193)$ & 0.629 \\
\hline & Hoof overgrowth & $95.8 \%(2298)$ & $94.0 \%(2257)$ & 0.007 \\
\hline & Hoof wall cracks & $2.2 \%(52)$ & $2.4 \%(57)$ & 0.628 \\
\hline
\end{tabular}

\subsection{Risk Factors for the Occurrence of Lameness and Lameness-Related Foot Lesions}

The effects of potential risk factors on the occurrence of lameness and lameness-related foot diseases and lesions are presented in Table 5. A one-degree increase on BCS (i) tended to be associated with ca. 2.9 times higher likelihood of foot-related lameness $(p=0.064)$, and (ii) was associated with ca. 3.7 times higher likelihood to develop OID lesions $(p<0.01)$. Additionally, ewes with good wool quality were ca. 2.3 times more likely to develop OID lesions $(p<0.05)$ compared to ewes with poor wool quality. Greater than four-year-old ewes were ca. 7.7 and 12.5 times more likely to develop IFR lesions compared to three $(p=0.064)$ and four-year-old $(p<0.05)$ ewes, respectively.

Table 5. Associations between (i) age, (ii) wool quality, (iii) body condition score and foot-related lameness and foot lesions at the animal level in the 600 studied ewes.

\begin{tabular}{|c|c|c|c|c|c|c|c|}
\hline \multirow[b]{2}{*}{ Parameter } & \multirow[b]{2}{*}{ Category Level } & \multirow[b]{2}{*}{$B$} & \multirow[b]{2}{*}{ SE } & \multirow[b]{2}{*}{$p$-Value } & \multirow[b]{2}{*}{ OR } & \multicolumn{2}{|c|}{$95 \%$ CI of OR } \\
\hline & & & & & & Lower & Upper \\
\hline \multicolumn{8}{|c|}{ Foot-related lameness } \\
\hline Age (years) & 2 & 0.39 & 0.569 & 0.492 & 1.48 & 0.48 & 4.52 \\
\hline & 3 & 0.23 & 0.609 & 0.708 & 1.26 & 0.38 & 4.16 \\
\hline & 4 & -0.16 & 0.538 & 0.767 & 0.85 & 0.30 & 2.45 \\
\hline & $>4$ & \multicolumn{6}{|c|}{ “Ref" } \\
\hline Wool quality & Good & -1.68 & 1.042 & 0.109 & 0.19 & 0.02 & 1.45 \\
\hline & Poor & \multicolumn{6}{|c|}{ "Ref" } \\
\hline $\begin{array}{l}\text { Body } \\
\text { condition } \\
\text { score }\end{array}$ & Continuous & 1.07 & 0.578 & 0.064 & 2.93 & 0.94 & 9.10 \\
\hline Intercept & Continuous & 0.94 & 1.909 & 0.624 & 2.55 & 0.06 & 108.44 \\
\hline
\end{tabular}


Table 5. Cont.

\begin{tabular}{|c|c|c|c|c|c|c|c|}
\hline \multirow[b]{2}{*}{ Parameter } & \multirow[b]{2}{*}{ Category Level } & \multirow[b]{2}{*}{$B$} & \multirow[b]{2}{*}{ SE } & \multirow[b]{2}{*}{$p$-Value } & \multirow[b]{2}{*}{ OR } & \multicolumn{2}{|c|}{$95 \%$ CI of OR } \\
\hline & & & & & & Lower & Upper \\
\hline \multicolumn{8}{|c|}{ Ovine interdigital dermatitis } \\
\hline Age (years) & 2 & -0.27 & 0.411 & 0.520 & 0.77 & 0.34 & 1.72 \\
\hline & 3 & -0.64 & 0.448 & 0.154 & 0.53 & 0.22 & 1.27 \\
\hline & 4 & -0.44 & 0.381 & 0.248 & 0.64 & 0.31 & 1.36 \\
\hline & $>4$ & \multicolumn{6}{|c|}{ "Ref" } \\
\hline Wool quality & Good & 0.81 & 0.342 & 0.018 & 2.25 & 1.15 & 4.40 \\
\hline & Poor & \multicolumn{6}{|c|}{ "Ref" } \\
\hline $\begin{array}{c}\text { Body } \\
\text { condition } \\
\text { score } \\
\end{array}$ & Continuous & 1.31 & 0.431 & 0.002 & 3.72 & 1.60 & 8.67 \\
\hline Intercept & Continuous & -2.57 & 1.272 & 0.044 & 0.08 & 0.01 & 0.93 \\
\hline \multicolumn{8}{|c|}{ Infectious footrot } \\
\hline Age (years) & 2 & -1.27 & 1.096 & 0.248 & 0.28 & 0.03 & 2.43 \\
\hline & 3 & -2.04 & 1.101 & 0.064 & 0.13 & 0.02 & 1.13 \\
\hline & 4 & -2.49 & 1.039 & 0.017 & 0.08 & 0.01 & 0.64 \\
\hline & $>4$ & \multicolumn{6}{|c|}{ "Ref" } \\
\hline Wool quality & Good & 0.37 & 0.512 & 0.476 & 1.44 & 0.53 & 3.93 \\
\hline $\begin{array}{l}\text { Body } \\
\text { condition } \\
\text { score }\end{array}$ & Continuous & -0.10 & 0.606 & 0.869 & 0.91 & 0.28 & 2.98 \\
\hline Intercept & Continuous & 4.48 & 2.027 & 0.028 & 88.11 & 1.64 & 4721.07 \\
\hline \multicolumn{8}{|c|}{ White line disease } \\
\hline Age (years) & 2 & 0.34 & 0.323 & 0.295 & 1.40 & 0.74 & 2.64 \\
\hline & 3 & 0.03 & 0.352 & 0.943 & 1.03 & 0.51 & 2.05 \\
\hline & 4 & -0.19 & 0.305 & 0.540 & 0.83 & 0.46 & 1.51 \\
\hline & $>4$ & \multicolumn{6}{|c|}{ "Ref" } \\
\hline Wool quality & $\begin{array}{l}\text { Good } \\
\text { Poor }\end{array}$ & \multicolumn{5}{|c|}{ "Ref" } & 2.15 \\
\hline $\begin{array}{l}\text { Body } \\
\text { condition } \\
\text { score }\end{array}$ & Continuous & 0.04 & 0.308 & 0.893 & 1.04 & 0.57 & 1.91 \\
\hline Intercept & Continuous & 0.20 & 0.922 & 0.825 & 1.23 & 0.20 & 7.49 \\
\hline \multicolumn{8}{|c|}{ Hoof wall cracks } \\
\hline Age (years) & 2 & 0.09 & 0.412 & 0.820 & 1.10 & 0.49 & 2.47 \\
\hline & 3 & -0.03 & 0.456 & 0.956 & 0.98 & 0.40 & 2.39 \\
\hline & 4 & -0.06 & 0.394 & 0.880 & 0.94 & 0.44 & 2.04 \\
\hline & $>4$ & \multicolumn{6}{|c|}{ "Ref" } \\
\hline Wool quality & Good & 0.19 & 0.386 & 0.623 & 1.21 & 0.57 & 2.58 \\
\hline & Poor & \multicolumn{6}{|c|}{ "Ref" } \\
\hline $\begin{array}{c}\text { Body } \\
\text { condition } \\
\text { score }\end{array}$ & Continuous & 0.52 & 0.404 & 0.203 & 1.67 & 0.76 & 3.70 \\
\hline Intercept & Continuous & 0.09 & 1.171 & 0.941 & 1.09 & 0.11 & 10.89 \\
\hline
\end{tabular}




\section{Discussion}

To the best of our knowledge, this is the first study assessing the epizootiology and distribution of foot diseases and lesions in intensively reared dairy sheep in Greece, addressing a significant dearth of knowledge and facilitating better understanding of footrelated lameness; OID and IFR were the most observed infectious foot diseases, whereas WLD and hoof wall cracks were the most common non-infectious hoof lesions. In addition, IFR was the major cause of lameness in the studied flocks.

In our study, a multivariate approach was utilized, integrating potential lameness risk factors as classifying variables to achieve an a posteriori typology of intensive farming systems. Similar approaches have been exploited in the past, to classify dairy small ruminant farms in Greece, based on their structure and characteristics, aiming to describe and understand the changes, challenges, and future perspectives of the sector [26,27]. Apart from milk yield and specific reproduction efficiency traits (empty ewes and abortion rate), no other remarkable differences were observed between the two clusters. Therefore, it can be assumed that a common evolutionary pattern exists in intensive dairy sheep farms in Greece; nevertheless, peculiarities of management and husbandry practices are likely to modify productivity and foot-health status. Cluster 1 farms had significantly increased milk yield per ewe per lactation and a higher prevalence of foot-related lameness and IFR compared to Cluster 2; hence, it could be hypothesized that sheep with higher milk yield are more susceptible to foot-related lameness. This is a hypothesis supported by studies in dairy cows showing that high yielding animals are more likely to develop foot lesions and lameness [23,28,29]; however, this is not sufficiently evidenced in dairy sheep [11], and under the current study-design, it is not possible neither to conclude the pathophysiological mechanisms nor estimate the effect of milk yield on foot-related lameness. Cohort studies comparing groups of high- and low-yielding ewes with regard the occurrence of footrelated lameness across lactation are necessary to address this hypothesis. On the contrary, the effect of foot-related lameness on milk yield has been documented in dairy sheep $[11,30]$. Similarly, in dairy cattle, foot-related lameness was associated with remarkable reduction on daily milk yield (from 1.6 to $2.7 \mathrm{~kg} /$ day; $[31,32]$ ) and milk yield per lactation period (from 270 to $574 \mathrm{~kg}$ [33]).

Overall prevalence of foot-related lameness in the studied ewes population $(9.0 \%)$ was increased compared to the mean prevalence reported by the farmers during the survey ( 2.4 and $5.3 \%$, for Cluster 1 and Cluster 2, respectively), and the estimated prevalence in intensive and semi-intensive Chios sheep farms in Greece about a decade ago (6.8\%) [30]. In the UK, results regarding prevalence of foot-related lameness are controversial, demonstrating either a reduction $[13,34,35]$ or an increase [21] compared to the average prevalence $(8.0-10.0 \%)$ reported 15 to 20 years ago $[36,37]$. The results of our study and the data from the UK indicate that lameness mitigation strategies are not universally efficient; also, we need to be cautious when interpreting the progression of foot-related lameness prevalence, as it is frequently underestimated by the farmers, due to different attitudes and beliefs and the underdiagnosis and underreporting of the problem [38,39]. Interestingly, in our study, foot-related lameness was considered by all farmers as a significant challenge for the health and welfare status of their flock. Nevertheless, most of them could recognize only severely lame animals and major foot diseases and lesions thereof (i.e., IFR, OID but not WLD); this is not consistent with sheep farmers in the UK, who could recognize even mildly lame sheep, although their attribute towards lameness varied [37].

OID was the most frequently observed infectious foot disease with almost one out of five animals in our study being diagnosed with the disease and the prevalence among the flocks varying from 7.0 to $48.0 \%$. Mean prevalence of OID in the UK has been estimated at $6.9 \%$ [13], however, prevalence up to $45.0 \%$ has been reported [40]. Frequently, OID is considered as the early stage of IFR and defined by infection and exudative inflammation signs at the interdigital space, caused by F. necrophorum before the invasion of $D$. nodosus and the underrunning of the hoof [41-43]. In our study, OID was separately assessed and defined by the occurrence of mild superficial lesions and loss of hair, limited at the 
interdigital space, without the occurrence of underrunning of the hoof wall. In general, early stages of OID either are not followed by lameness, or result in unnoticed lameness cases [43]; this is consistent with our findings where mild to moderate OID cases were observed and not found to be associated with lameness unless IFR co-existed. Absence of lameness indicates that OID is possible to remain underdiagnosed or undiagnosed in intensive sheep farms until its complication by $D$. nodosus and the development of IFR. Furthermore, OID was more commonly observed at the rear limbs compared to the front limbs. According to the available literature, this is the first time that differences between front and rear limbs regarding OID infections are observed in sheep. However, this is in agreement with the distribution of lesions due to infectious foot diseases in both dairy cows and beef cattle $[23,44-46]$. In the case of dairy cows, it has been suggested that the closer contact of rear limbs with manure (F. necrophorum is normally found on the digestive tract), and potentially body weight distribution, may explain the susceptibility of rear limbs to the disease. Nevertheless, in sheep farms, manure and bedding material are drier than in cow farms, whereas research on weight distribution and posture/gait biomechanics is scarce; hence, support or rejection of these hypotheses are not feasible.

IFR is a globally spread and exceptionally contagious and painful disease of the foot. It is considered the most significant lameness-related bacterial foot disease in sheep causing extended foot lesions [47]. These lesions include the underrunning of the hoof, and in advanced cases, the total separation of the horn from the underlying hoof matrix $[43,48,49]$. Its prevalence in meat sheep varies from negligible $(0.4 \%$, [50]) or moderate $(3.7 \%$ [37]; $8.5 \%$ [51]) to high ( $>40.0 \%$ [52]) or extremely high ( $>95.0 \%$ [43]) and its transmission occurs mainly in damp conditions, rather than in dry, hot, and cold conditions [53]. Under the UK temperate climate, 80.0 to $90.0 \%$ of sheep flocks are affected by IFR [21,54], with the annual cost of the disease estimated between GBP 20 to 80 million [55,56]. In our study, IFR was observed in all the studied flocks, and $8.0 \%$ of the studied ewes were affected by IFR in at least one hoof; this is within the expected prevalence range, considering that recordings took place in autumn, when warm weather and high moisture favor survival, proliferation, and transmission of F. necrophorum and D. nodosus [9,42,49]. IFR was present in $87.0 \%(47 / 54)$ of the ewes with lameness alone or in combination with other foot lesions. This finding underlines its significance in the epizootiology of foot-related lameness in intensive dairy sheep farms, which is in agreement with Gelasakis et al. [30] and Kaler and Green [37] who documented that more than 60.0 and $90.0 \%$ of lameness cases were due to IFR in dairy and meat sheep, respectively. IFR had a significantly higher prevalence in cluster 1 ewes, when examined at the limb and the hoof level, implying an association between high milk yield and susceptibility to IFR, which is consistent with findings in dairy cows [28]. IFR was more commonly observed at rear limbs and hooves compared to front limbs and hooves, possibly explained by the mechanism detailed for OID. As expected, and in compliance with the available literature, no significant differences were found between inner and outer hooves as regards to the occurrence of the disease.

The most prevalent foot lesion in the studied sheep population was WLD (ca. 38.0\%). High prevalence of WLD is not unusual. Previous studies have reported prevalence as high as $75.0 \%$ in some flocks $[10,57]$. WLD occurs when the hoof wall is detached from the laminar corium, a condition that is usually underdiagnosed or under-reported by the farmers who are unable to recognize it. This was also the case in the surveyed farms. Thereby, high prevalence of WLD could be associated with misdiagnosis and the absence of efficient treatment. In most cases, WLD is not directly associated to lameness, but predisposes to it due to debris accumulation inside the defect, leading to proliferation of bacteria, foot infection, abscess formation (WLA), pain and lameness. Although, the etiology and risk factors of WLD remain unknown in sheep [10], type of ground [58] and nutritional deficiencies (biotin and sulfur containing amino acids) are considered as causative or predisposing factors in dairy cattle [59]. Moreover, genetic background has recently been evidenced for WLD in meat sheep breeds using data from 9169 sheep and 22 farms with increased WLD prevalence $(47.0 \%$ and $24.0 \%$, for Scottish Blackface and Texel 
sheep, respectively) in the UK [57]. In dairy sheep, data regarding the epizootiology of WLD is limited. Recently, Gelasakis et al. [30] reported white line lesions (WLD and WLA) as the second most significant cause of foot-related lameness in intensively reared Chios sheep (with an incidence risk of $1.1 \%$ and $0.8 \%$, respectively); however, only lame animals were included in that study. Regarding the distribution of WLD lesions at the limb and the hoof level, no significant differences were found, which agrees with findings from dairy goats in the UK [60]; hence, it could be assumed that WLD is not likely to be associated with (i) body weight distribution and biomechanics during standing and walking, (ii) anatomical peculiarities of hooves, and (iii) different environmental exposures, at the limb or the hoof level (e.g., associated with their placement, front/rear or inner/outer). In the present study, none of the factors assessed was found to affect the prevalence of WLD. Breed has been found to predispose in WLD in both meat sheep and dairy cows, whereas WLD prevalence in cows increased with age and milk yield [58,61]. Although we used only purebred animals of different breeds, the breed effect could not be estimated as it was confounded by the farm effect. When assessed at the hoof level, WLD tended to be most prevalent in Cluster 2 ewes $(p=0.06)$, indicating that differences between intensive farming systems regarding WLD prevalence are likely to occur. In every case, it can be concluded that a different study-design (e.g., cohort study) should be exploited to investigate the etiopathogenesis and epizootiology of WLD.

This is the first time hoof wall cracks in dairy sheep are studied, whereas relevant studies in meat and wool sheep are also not available. Hoof wall cracks were observed in ca. $15.0 \%$ of the ewes. Based on horse and cattle studies, inappropriate housing conditions, poor bedding, increased moisture, manure exposition, vitamin and trace mineral deficiencies, poor-quality hoof keratin and hoof conformation, as well as increased age and BCS lead to the disruption of hoof wall integrity and may predispose to hoof wall cracks and injuries [62-66]. Poor wool quality could be linked to a higher prevalence of hoof wall cracks, due to the fact that keratin of both wool and hoof horn have similar low- and highsulfur protein fractions [67-69]; however, this was not confirmed by the model applied in our study. In dairy cows, a much lower prevalence $(1.0 \%)$ of hoof wall cracks has been found, compared to beef cows (64.0\%), mainly in the outer, front hooves associated with the gait pattern and the charging of the front limbs [66,70]. In our study, no significant differences were found between the clusters, front/rear limbs and hooves, and inner/outer hooves, whereas none of the traits assessed as risk factors had a significant effect.

Inappropriate foot care (i.e., foot-trimming and foot-bathing), also predisposes to foot-related lameness. Indeed, severe hoof overgrowth may cause foot deformities and is likely to predispose to infectious foot diseases, foot lesions, and lameness [71]. The majority of farms in the present study exercised routine foot-trimming once per year. Foot baths are rarely used, if at all. As expected, overgrown hooves were observed in almost all the studied animals regardless of cluster or farm. For this reason, the observed differences regarding hoof overgrowth at the limb and the hoof level are biologically meaningless. In dairy cows, differences between front and rear hooves regarding prevalence and severity of hoof overgrowth have been documented, with front hooves being more frequently severely overgrown [72]. In permanently housed dairy sheep, hooves are not worn-down. Animals usually walk on soft straw bedding material which does not favor natural wearing of the hoof. In addition, increased intake of concentrates in high yielding sheep further deteriorates the situation by increasing the growth rate of the hoof horn [73]. In the studied farms, excessive hoof overgrowth implies that routine foot-trimming once per year was not adequate, hence, twice per year may be necessary (i) to maintain normal shape and conformation of the hooves and the uninterrupted movement of the animals, (ii) to avoid injuries and infections, and (iii) for the early diagnosis and allocation of foot-lesions. In every case, it is crucial that foot-trimming is performed by experienced foot-trimmers to avoid excessive trimming leading to injuries and bleeding. According to Winter et al. [13], the remarkable decrease in the prevalence of sheep lameness in England from 2004 to 2013 in meat breeds was linked to (i) the control of excessive foot-trimming, (ii) the prompt 
treatment of lameness, and (iii) the overall training and knowledge-transfer to farmers for the management of lameness. Based on this observation, they concluded that foottrimming should be excluded from routine foot care practices, as its benefits were not evidenced. However, extrapolating observations from meat sheep, reared under grazing systems where natural worn-down of the hooves occurs, is not appropriate.

Season is among the environmental factors affecting foot-related lameness in both meat [74] and dairy sheep [9]. Our study was performed between mid to late autumn (from October to December), where increased moisture and relatively warm weather in combination with accumulating manure facilitate the proliferation and transmission of pathogens causing infectious foot diseases, thus justifying the observed high prevalence of OID and IFR $[42,74]$. Under the current study-design, it was not possible to assess the seasonal variation of infectious foot diseases prevalence, and a longitudinal study is warranted to address this objective. A similar study was recently implemented in meat sheep, demonstrating increased prevalence of IFR during late summer/early autumn and spring [74].

Farming system influences the etiology and epizootiology of foot-related lameness in dairy sheep [9], with intensive farms being more challenged [39]. In intensive farms, increased stocking density [13] and inappropriate hygiene conditions [75] predispose to foot diseases and lameness thereof. Hence, increased stocking density in Cluster 2 could explain the significantly higher prevalence of OID, ocular and/or nasal discharge, mastitis, and udder skin lesions, as well as the dirtier fleece of the ewes. Noteworthy differences regarding basic hygiene and biosecurity protocols were not recorded among the farms; routine cleaning and disinfection of the premises, with commercial disinfectants, at least twice per year, during early autumn and spring were practiced in all cases following standard procedures.

Average BCS of the studied ewes was acceptable (2.8) for the production stage (early lactation). Ideally, BCS during early lactation should be 3.0, however, negative energy balance at this stage in high-yielding dairy ewes is common resulting in a rather expected reduction on BCS during the first weeks of lactation [76]. Ewes with higher BCS were more likely to be diagnosed with OID. It is the first time such a relationship is observed in dairy sheep, although similar observations have been previously reported in dairy cows where heavier animals had increased probability of developing non-infectious hoof disorders [77]. Similarly, ewes with better wool quality in the present study had a higher risk of being infected by OID. Most OID cases were mild and not complicated by IFR; it can be hypothesized that ewes with better wool quality and/or higher BCS had a better quality of hoof horn preventing the transition from OID to IFR and lameness.

In the studied flocks, distribution of animals within the four age groups was not equal, although animals were randomly selected. Nationwide drop of sheep milk price by 20.0 to $25.0 \%$ in 2017-2018 resulted in a wide reduction of the replacement rate that year, to decrease replacement cost. This was also the case in the studied flocks, leading to a reduced three-yearold age group. Random selection of animals and analyses performed were adequate to handle and compare data between unequally sized age groups. Greater than four-year-old ewes had significantly increased probabilities of developing IFR compared to three- and four-year-old ewes. This is consistent with several studies in meat sheep $[16,43,74]$, and is probably the result of increased susceptibility to footrot and hoof deterioration with age [16]. This is also supported by several studies in dairy cows [78-83], where increased prevalence of infectious foot-diseases with age is attributed to (i) hoof deformities associated with metabolic and other stressors [78,84], (ii) changes in the loading capacity of the sole and other soft tissues of the feet [85], (iii) longer exposure to housing environment and pathogens [78], and (iv) inadequate treatment and relapsing foot lesions [81].

\section{Conclusions}

A remarkable prevalence of foot-related lameness, foot diseases and lesions in intensive dairy sheep farms in Greece has been evidenced, indicating an increasing trend over the last decade. This underpins the urgent demand for targeted mitigation strategies 
against foot-health challenging conditions and particularly infectious foot diseases (i.e., IFR and OID). These strategies need to adjust on the peculiarities of intensive livestock farming and should be mainly based on (i) hygiene and biosecurity measures, (ii) preventive veterinary measures and control of foot diseases and lesions, and (iii) training of farmers on foot care practices and holistic management of foot health and lameness. Among the studied risk factors, age, and BCS were associated with infectious foot diseases; however, further investigation of potential risk factors in cohort and large-scale studies are crucial to elucidate their effects. Building on current knowledge and covering of the gaps in the epizootiology and potential risk factors of foot-related lameness, diseases, and lesions will further enhance health and welfare of dairy sheep and the sustainability of farms.

Author Contributions: Conceptualization, A.I.G., M.M., A.I.K. and P.S.; methodology, M.M., A.I.K., P.S. and A.I.G.; software, A.I.G. and M.M.; validation, A.I.G. and I.B.; formal analysis, M.M., A.I.G. and A.I.K.; investigation, M.M., A.I.K., G.P. and S.P.; resources, A.I.G., M.M. and A.I.K.; data curation, M.M. and A.I.K.; writing-original draft preparation, M.M. and A.I.K.; writing-review and editing, A.I.G., P.S. and I.B.; visualization, A.I.G., M.M. and A.I.K.; supervision, A.I.G.; project administration, A.I.G. and P.S.; funding acquisition, A.I.G., M.M., A.I.K. and P.S. All authors have read and agreed to the published version of the manuscript.

Funding: This research is co-financed by Greece and the European Union (European Social FundESF) through the Operational Programme «Human Resources Development, Education and Lifelong Learning 2014-2020» in the context of the project "Epizootiological investigation of foot-related lameness, assessment of relevant risk factors and development of a protocol for its diagnosis, prediction and control in intensive dairy sheep flocks" (MIS5048473).

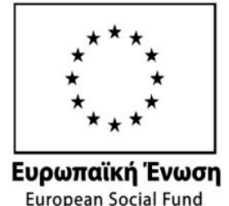

\section{Operational Programme Human Resources Development, Education and Lifelong Learning}

Co-financed by Greece and the European Union

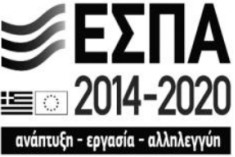

Institutional Review Board Statement: The study was conducted in compliance with the national animal welfare regulations i.e., the Presidential Decree 56/13 “Bringing Greek legislation into line with Directive 2010/63/EC of the European Parliament and of the Council of 22 September 2010 (L $276 / 33 / 20.10 .2010)$ regarding the protection of animals used for experimental and other scientific purposes". The applied diagnostic veterinary procedures are not within the context of relevant EU legislation for animal experimentations (Directive 86/609/EC) and may be performed in order to diagnose animal diseases and improve animal welfare. In the current study, physical examination of animals and foot-trimming were performed by experienced vets and foot-trimmers as part of routine, non-experimental clinical assessment and foot-care practices for the diagnosis, control of and protection against diseases, foot lesions and related lameness cases. Consent was ensured by farm owners.

Informed Consent Statement: Not applicable.

Acknowledgments: Farmers participated in the study are greatly acknowledged for their collaboration; Theodoros Pneumatikos, Fotini Chrysanthakopoulou, Georgios Komatsioulis, Vassiliki Doulma, and Gerasimos Katsaganis are acknowledged for their help with farm work and data collection.

Conflicts of Interest: The authors declare no conflict of interest.

\section{References}

1. FAOSTAT. Live Animals. Available online: http://www.fao.org/faostat/en/?\#data/QA (accessed on 29 April 2021).

2. Ripoll-Bosch, R.; Díez-Unquera, B.; Ruiz, R.; Villalba, D.; Molina, E.; Joy, M.; Olaizola, A.; Bernués, A. An integrated sustainability assessment of mediterranean sheep farms with different degrees of intensification. Agric. Syst. 2012, 105, 46-56. [CrossRef]

3. Broom, D.M. Animal welfare: An aspect of care, sustainability, and food quality required by the public. J. Vet. Med. Educ. 2010, 37, 83-88. [CrossRef]

4. Gamborg, C.; Sandøe, P. Sustainability in farm animal breeding: A review. Livest. Prod. Sci. 2005, 92, 221-231. [CrossRef] 
5. Velarde, A.; Fàbrega, E.; Blanco-Penedo, I.; Dalmau, A. Animal welfare towards sustainability in pork meat production. Meat Sci. 2015, 109, 13-17. [CrossRef] [PubMed]

6. Buller, H.; Blokhuis, H.; Jensen, P.; Keeling, L. Towards farm animal welfare and sustainability. Animals 2018, 8, 81. [CrossRef]

7. Kilgour, R.J.; Waterhouse, T.; Dwyer, C.M.; Ivanov, I.D. Farming systems for sheep production and their effect on welfare. In The Welfare of Sheep; Dwyer, C., Ed.; Springer: Edinburgh, UK, 2013; Volume 53, pp. 213-265. ISBN 9788578110796.

8. Fourichon, C.; Beaudeau, F.; Bareille, N.; Seegers, H. Incidence of health disorders in dairy farming systems in western France. Livest. Prod. Sci. 2001, 68, 157-170. [CrossRef]

9. Gelasakis, A.I.; Kalogianni, A.I.; Bossis, I. Aetiology, risk factors, diagnosis and control of foot-related lameness in dairy sheep. Animals 2019, 9, 509. [CrossRef]

10. Winter, A.C. Lameness in sheep. Small Rumin. Res. 2008, 76, 149-153. [CrossRef]

11. Gelasakis, A.I.; Arsenos, G.; Valergakis, G.E.; Banos, G. Association of lameness with milk yield and lactation curves in Chios dairy ewes. J. Dairy Res. 2015, 82, 193-199. [CrossRef]

12. Marshall, D.J.; Walker, R.I.; Cullis, B.R.; Luff, M.F. The effect of footrot on body weight and wool growth of sheep. Aust. Vet. J. 1991, 68, 45-49. [CrossRef] [PubMed]

13. Winter, J.R.; Kaler, J.; Ferguson, E.; KilBride, A.L.; Green, L.E. Changes in prevalence of, and risk factors for, lameness in random samples of English sheep flocks: 2004-2013. Prev. Vet. Med. 2015, 122, 121-128. [CrossRef]

14. O’Brien, A.C.; McHugh, N.; Wall, E.; Pabiou, T.; McDermott, K.; Randles, S.; Fair, S.; Berry, D.P. Genetic parameters for lameness, mastitis and dagginess in a multi-breed sheep population. Animal 2016, 11, 911-919. [CrossRef]

15. Barker, Z.E.; Leach, K.A.; Whay, H.R.; Bell, N.J.; Main, D.C.J. Assessment of lameness prevalence and associated risk factors in dairy herds in England and Wales. J. Dairy Sci. 2010, 93, 932-941. [CrossRef]

16. Kaler, J.; Medley, G.F.; Grogono-Thomas, R.; Wellington, E.M.H.; Calvo-Bado, L.A.; Wassink, G.J.; King, E.M.; Moore, L.J.; Russell C.; Green, L.E. Factors associated with changes of state of foot conformation and lameness in a flock of sheep. Prev. Vet. Med. 2010, 97, 237-244. [CrossRef] [PubMed]

17. Gelasakis, A.I.; Arsenos, G.; Hickford, J.; Zhou, H.; Psifidi, A.; Valergakis, G.E.; Banos, G. Polymorphism of the MHC-DQA2 gene in the Chios dairy sheep population and its association with footrot. Livest. Sci. 2013, 153, 56-59. [CrossRef]

18. Gelasakis, A.I.; Valergakis, G.E.; Arsenos, G. Predisposing factors of sheep lameness. J. Hell. Vet. Med. Soc. 2009, 60, 63-74. [CrossRef]

19. Vittis, Y.; Kaler, J. Environmental and field characteristics associated with lameness in sheep: A study using a smartphone lameness app for data recording. Vet. Rec. 2020, 186, 384. [CrossRef] [PubMed]

20. Duncan, J.S.; Angell, J.W.; Carter, S.D.; Evans, N.J.; Sullivan, L.E.; Grove-White, D.H. Contagious ovine digital dermatitis: An emerging disease. Vet. J. 2014, 201, 265-268. [CrossRef] [PubMed]

21. Duncan, J.; Angell, J. Control of infectious lameness in sheep. Livestock 2019, 24, 246-251. [CrossRef]

22. Cook, N.B. Prevalence of lameness among dairy cattle in Wisconsin as a function of housing type and stall surface. J. Am. Vet. Med. Assoc. 2003, 223, 1324-1328. [CrossRef]

23. Bicalho, R.C.; Oikonomou, G. Control and prevention of lameness associated with claw lesions in dairy cows. Livest. Sci. 2013, 156, 96-105. [CrossRef]

24. Haskell, M.J.; Rennie, L.J.; Bowell, V.A.; Bell, M.J.; Lawrence, A.B. Housing system, milk production, and zero-grazing effects on lameness and leg injury in dairy cows. J. Dairy Sci. 2006, 89, 4259-4266. [CrossRef]

25. Russel, A.J.F.; Doney, J.M.; Gunn, R.G. Subjective assessment of body fat in live sheep. J. Agric. Sci. 1969, 72, 451-454. [CrossRef]

26. Gelasakis, A.I.; Valergakis, G.E.; Arsenos, G.; Banos, G. Description and typology of intensive Chios dairy sheep farms in Greece. J. Dairy Sci. 2012, 95, 3070-3079. [CrossRef]

27. Gelasakis, A.I.; Rose, G.; Giannakou, R.; Valergakis, G.E.; Theodoridis, A.; Fortomaris, P.; Arsenos, G. Typology and characteristics of dairy goat production systems in Greece. Livest. Sci. 2017, 197, 22-29. [CrossRef]

28. Osová, A.; Mihajlovičová, X.; Hund, A.; Mudroň, P. Interdigital phlegmon (foot rot) in dairy cattle-An update. Wien. Tierarztl. Mon. 2017, 104, 209-220.

29. Green, L.E.; Huxley, J.N.; Banks, C.; Green, M.J. Temporal associations between low body condition, lameness and milk yield in a UK dairy herd. Prev. Vet. Med. 2014, 113, 63-71. [CrossRef] [PubMed]

30. Gelasakis, A.I.; Oikonomou, G.; Bicalho, R.C.; Valergakis, G.E.; Fthenakis, G.S.; Arsenos, G. Clinical characteristics of lameness and potential risk factors in intensive and semi-intensive dairy sheep flocks in Greece. J. Hell. Vet. Med. Soc. 2013, 64, 123-130. [CrossRef]

31. King, M.T.M.; LeBlanc, S.J.; Pajor, E.A.; DeVries, T.J. Cow-level associations of lameness, behavior, and milk yield of cows milked in automated systems. J. Dairy Sci. 2017, 100, 4818-4828. [CrossRef]

32. Randall, L.V.; Green, M.J.; Chagunda, M.G.G.; Mason, C.; Green, L.E.; Huxley, J.N. Lameness in dairy heifers; impacts of hoof lesions present around first calving on future lameness, milk yield and culling risk. Prev. Vet. Med. 2016, 133, 52-63. [CrossRef]

33. Huxley, J.N. Impact of lameness and claw lesions in cows on health and production. Livest. Sci. 2013, 156, 64-70. [CrossRef]

34. Wild, R.; McFadden, A.M.J.; O'Connor, C.; O'Grady, K.; Wada, M. Prevalence of lameness in sheep transported to meat processing plants in New Zealand and associated risk factors. N. Zealand Vet. J. 2019, 67, 188-193. [CrossRef]

35. Liu, N.L.B.H.; Kaler, J.; Ferguson, E.; O'Kane, H.; Green, L.E. Sheep farmers' attitudes to farm inspections and the role of sanctions and rewards as motivation to reduce the prevalence of lameness. Anim. Welf. 2018, 27, 67-79. [CrossRef] 
36. Wassink, G.J.; Grogono-Thomas, R.; Moore, L.J.; Green, L.E. Risk factors associated with the prevalence of footrot in sheep from 1999 to 2000. Vet. Rec. 2003, 152, 351-358. [CrossRef] [PubMed]

37. Kaler, J.; Green, L.E. Naming and recognition of six foot lesions of sheep using written and pictorial information: A study of 809 English sheep farmers. Prev. Vet. Med. 2008, 83, 52-64. [CrossRef]

38. O'Kane, H.; Ferguson, E.; Kaler, J.; Green, L. Associations between sheep farmer attitudes, beliefs, emotions and personality, and their barriers to uptake of best practice: The example of footrot. Prev. Vet. Med. 2017, 139, 123-133. [CrossRef] [PubMed]

39. Nalon, E.; Stevenson, P. Addressing lameness in farmed animals: An urgent need to achieve compliance with EU animal welfare law. Animals 2019, 9, 576. [CrossRef]

40. Hodgkinson, O. The importance of feet examination in sheep health management. Small Rumin. Res. 2010, 92, 67-71. [CrossRef]

41. Conington, J.; Hosie, B.; Nieuwhof, G.J.; Bishop, S.C.; Bünger, L. Breeding for resistance to footrot-The use of hoof lesion scoring to quantify footrot in sheep. Vet. Res. Commun. 2008, 32, 583-589. [CrossRef] [PubMed]

42. Grøneng, G.M.; Green, L.E.; Kaler, J.; Vatn, S.; Hopp, P. A longitudinal study of the risks for introduction of severe footrot into sheep flocks in the south west of Norway. Prev. Vet. Med. 2014, 113, 241-248. [CrossRef]

43. Raadsma, H.W.; Egerton, J.R. A review of footrot in sheep: Aetiology, risk factors and control methods. Livest. Sci. 2013, 156, 106-114. [CrossRef]

44. Somers, J.; O'Grady, L. Foot lesions in lame cows on 10 dairy farms in Ireland. Ir. Vet. J. 2015, 68, 1-7. [CrossRef] [PubMed]

45. Solano, L.; Barkema, H.W.; Mason, S.; Pajor, E.A.; LeBlanc, S.J.; Orsel, K. Prevalence and distribution of foot lesions in dairy cattle in Alberta, Canada. J. Dairy Sci. 2016, 99, 6828-6841. [CrossRef] [PubMed]

46. Newcomer, B.W.; Chamorro, M.F. Distribution of lameness lesions in beef cattle: A retrospective analysis of 745 cases. Can. Vet. J. 2016, 57, 401-406. [PubMed]

47. Abbott, K.A.; Lewis, C.J. Current approaches to the management of ovine footrot. Vet. J. 2005, 169, 28-41. [CrossRef]

48. Witcomb, L.A.; Green, L.E.; Kaler, J.; Ul-Hassan, A.; Calvo-Bado, L.A.; Medley, G.F.; Grogono-Thomas, R.; Wellington, E.M.H. A longitudinal study of the role of Dichelobacter nodosus and Fusobacterium necrophorum load in initiation and severity of footrot in sheep. Prev. Vet. Med. 2014, 115, 48-55. [CrossRef] [PubMed]

49. Zanolari, P.; Dürr, S.; Jores, J.; Steiner, A.; Kuhnert, P. Ovine footrot: A review of current knowledge. Vet. J. 2021, $271,105647$. [CrossRef]

50. Byrne, D.T.; Esmonde, H.; Berry, D.P.; McGovern, F.; Creighton, P.; McHugh, N. Sheep lameness detection from individual hoof load. Comput. Electron. Agric. 2019, 158, 241-248. [CrossRef]

51. Bennett, G.N.; Hickford, J.G.H. Ovine footrot: New approaches to an old disease. Vet. Microbiol. 2011, 148, 1-7. [CrossRef]

52. Duncan, J.S.; Grove-White, D.; Moks, E.; Carroll, D.; Oultram, J.W.; Phythian, C.J.; Williams, H.W. Impact of footrot vaccination and antibiotic therapy on footrot and contagious ovine digital dermatitis. Vet. Rec. 2012, 170, 462. [CrossRef]

53. Clifton, R.; Giebel, K.; Liu, N.L.B.H.; Purdy, K.J.; Green, L.E. Sites of persistence of Fusobacterium necrophorum and Dichelobacter nodosus: A paradigm shift in understanding the epidemiology of footrot in sheep. Sci. Rep. 2019, 9, 1-11. [CrossRef]

54. Kaler, J.; Green, L.E. Farmers' practices and factors associated with the prevalence of all lameness and lameness attributed to interdigital dermatitis and footrot in sheep flocks in England in 2004. Prev. Vet. Med. 2009, 92, 52-59. [CrossRef]

55. Nieuwhof, G.J.; Bishop, S.C. Costs of the major endemic diseases of sheep in Great Britain and the potential benefits of reduction in disease impact. Anim. Sci. 2005, 81, 23-29. [CrossRef]

56. Wassink, G.J.; King, E.M.; Grogono-Thomas, R.; Brown, J.C.; Moore, L.J.; Green, L.E. A within farm clinical trial to compare two treatments (parenteral antibacterials and hoof trimming) for sheep lame with footrot. Prev. Vet. Med. 2010, 96, 93-103. [CrossRef]

57. Conington, J.; Nicoll, L.; Mitchell, S.; Bünger, L. Characterisation of white line degeneration in sheep and evidence for genetic influences on its occurrence. Vet. Res. Commun. 2010, 34, 481-489. [CrossRef] [PubMed]

58. Kujala, M.; Dohoo, I.R.; Soveri, T. White-line disease and haemorrhages in hooves of Finnish dairy cattle. Prev. Vet. Med. 2010, 94, 18-27. [CrossRef]

59. Winter, A.; Arsenos, G. Diagnosis of white line lesions in sheep. Practice 2009, 31, 17-21. [CrossRef]

60. Hill, N.P.; Murphy, P.E.; Nelson, A.J.; Mouttotou, N.; Green, L.E.; Morgan, K.L. Lameness and foot lesions in adult British dairy goats. Vet. Rec. 1997, 141, 412-416. [CrossRef] [PubMed]

61. Amory, J.R.; Barker, Z.E.; Wright, J.L.; Mason, S.A.; Blowey, R.W.; Green, L.E. Associations between sole ulcer, white line disease and digital dermatitis and the milk yield of 1824 dairy cows on 30 dairy cow farms in England and Wales from February 2003-November 2004. Prev. Vet. Med. 2008, 83, 381-391. [CrossRef] [PubMed]

62. Holzhauer, M.; Bremer, R.; Santman-Berends, I.; Smink, O.; Janssens, I.; Back, W. Cross-sectional study of the prevalence of and risk factors for hoof disorders in horses in The Netherlands. Prev. Vet. Med. 2017, 140, 53-59. [CrossRef]

63. Pleasant, R.S.; O'Grady, S.E.; McKinlay, I. Farriery for Hoof Wall Defects. Quarter Cracks and Toe Cracks. Vet. Clin. N. Am. Equine Pract. 2012, 28, 393-406. [CrossRef]

64. Rahman, M.; Imtiaz, M.; Ahaduzzaman, M.; Ghosh, K.; Masud, A.; Chowdhury, S.; Sikder, S. Effects of flooring and rearing system on hoof health of dairy cows in some selected areas of Bangladesh. Bangladesh J. Anim. Sci. 2014, 43, 132-137. [CrossRef]

65. Goonewardene, L.A.; Hand, R.K. A study of hoof cracks in grazing cattle-Association of age, weight and fatness. Can. J. Anim. Sci. 1995, 75, 25-29. [CrossRef]

66. Jubb, T.F.; Malmo, J. Lesions causing lameness requiring veterinary treatment in pasture-fed dairy cows in east Gippsland. Aust. Vet. J. 1991, 68, 21-24. [CrossRef] 
67. Kui, H.; Liu, X.; Liu, J.; Liang, W.; Zhang, S.; Qian, Z.; Ren, L. The passive contact stability of blue sheep hoof based on structure, mechanical properties, and surface morphology. Front. Bioeng. Biotechnol. 2020, 8, 1-16. [CrossRef]

68. Tomlinson, D.J.; Mülling, C.H.; Fakler, T.M. Invited review: Formation of keratins in the bovine claw: Roles of hormones, minerals, and vitamins in functional claw integrity. J. Dairy Sci. 2004, 87, 797-809. [CrossRef]

69. Wang, B.; Zhou, B.; Zhang, X.; Wang, B. Microstructure and mechanical properties of an alpha keratin bovine hoof wall. J. Mech. Behav. Biomed. Mater. 2020, 104, 103689. [CrossRef]

70. Hand, R.K.; Goonewardene, L.A.; Yaremcio, B.J.; Westra, R. A study on the prevalence of cracked claws among beef cows. Can. J. Anim. Sci. 1992, 72, 165-168. [CrossRef]

71. Azizi, S.; Tehrani, A.A.; Dalir-Naghadeh, B.; Hemmati, M. The effects of farming system and season on the prevalence of lameness in sheep in northwest Iran. N. Zealand Vet. J. 2011, 59, 311-316. [CrossRef]

72. Murray, R.D.; Downham, D.Y.; Clarkson, M.J.; Faull, W.B.; Hughes, J.W.; Manson, F.J.; Merritt, J.B.; Russell, W.B.; Sutherst, J.E.; Ward, W.R. Epidemiology of lameness in dairy cattle: Description and analysis of foot lesions. Vet. Rec. 1996, 138, 586-591. [CrossRef]

73. Shelton, J.; Usherwood, N.M.; Wapenaar, W.; Brennan, M.L.; Green, L.E. Measurement and error of hoof horn growth rate in sheep. J. Agric. Sci. 2012, 150, 373-378. [CrossRef]

74. Angell, J.W.; Grove-White, D.H.; Duncan, J.S. Sheep and farm level factors associated with footrot: A longitudinal repeated cross-sectional study of sheep on six farms in the UK. Vet. Rec. 2018, 182, 107-120. [CrossRef]

75. Green, L.E.; George, T.R.N. Assessment of current knowledge of footrot in sheep with particular reference to Dichelobacter nodosus and implications for elimination or control strategies for sheep in Great Britain. Vet. J. 2008, 175, 173-180. [CrossRef]

76. Kenyon, P.R.; Maloney, S.K.; Blache, D. Review of sheep body condition score in relation to production characteristics. N. Zealand J. Agric. Res. 2014, 57, 38-64. [CrossRef]

77. Pérez-Cabal, M.A.; Charfeddine, N. Short communication: Association of foot and leg conformation and body weight with claw disorders in Spanish Holstein cows. J. Dairy Sci. 2016, 99, 9104-9108. [CrossRef] [PubMed]

78. Oehm, A.W.; Knubben-Schweizer, G.; Rieger, A.; Stoll, A.; Hartnack, S. A systematic review and meta-analyses of risk factors associated with lameness in dairy cows. BMC Vet. Res. 2019, 15, 1-14. [CrossRef]

79. Jewell, M.T.; Cameron, M.; Spears, J.; McKenna, S.L.; Cockram, M.S.; Sanchez, J.; Keefe, G.P. Prevalence of lameness and associated risk factors on dairy farms in the Maritime Provinces of Canada. J. Dairy Sci. 2019, 102, 3392-3405. [CrossRef]

80. Randall, L.V.; Green, M.J.; Chagunda, M.G.G.; Mason, C.; Archer, S.C.; Green, L.E.; Huxley, J.N. Low body condition predisposes cattle to lameness: An 8-year study of one dairy herd. J. Dairy Sci. 2015, 98, 3766-3777. [CrossRef]

81. Solano, L.; Barkema, H.W.; Pajor, E.A.; Mason, S.; LeBlanc, S.J.; Zaffino Heyerhoff, J.C.; Nash, C.G.R.; Haley, D.B.; Vasseur, E.; Pellerin, D.; et al. Prevalence of lameness and associated risk factors in Canadian Holstein-Friesian cows housed in freestall barns. J. Dairy Sci. 2015, 98, 6978-6991. [CrossRef] [PubMed]

82. Sarjokari, K.; Kaustell, K.O.; Hurme, T.; Kivinen, T.; Peltoniemi, O.A.T.; Saloniemi, H.; Rajala-Schultz, P.J. Prevalence and risk factors for lameness in insulated free stall barns in Finland. Livest. Sci. 2013, 156, 44-52. [CrossRef]

83. Capion, N.; Thamsborg, S.M.; Enevoldsen, C. Prevalence of foot lesions in Danish Holstein cows. Vet. Rec. 2008, 163, 80-86. [CrossRef] [PubMed]

84. Moreira, T.F.; Nicolino, R.R.; Meneses, R.M.; Fonseca, G.V.; Rodrigues, L.M.; Facury Filho, E.J.; Carvalho, A.U. Risk factors associated with lameness and hoof lesions in pasture-based dairy cattle systems in southeast Brazil. J. Dairy Sci. 2019, 102, 10369-10378. [CrossRef] [PubMed]

85. Bran, J.A.; Daros, R.R.; von Keyserlingk, M.A.G.; LeBlanc, S.J.; Hötzel, M.J. Cow- and herd-level factors associated with lameness in small-scale grazing dairy herds in Brazil. Prev. Vet. Med. 2018, 151, 79-86. [CrossRef] [PubMed] 